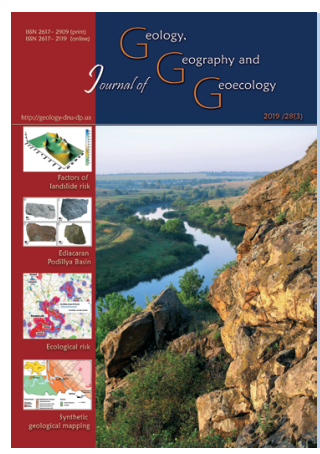

Journal of Geology.

ISSN 2617-2909 (print)

ISSN 2617-2119 (online)

Geography and

Geoecology

Journ.Geol.Geograph.

Geology,

28(3), 495-503.

Journal home page: geology-dnu-dp.ua

doi: $10.15421 / 111945$

T. P. Mokritskaya

Journ. Geol. Geograph. Geoecology, 28(3), 495-503.

\title{
On different types, conditions, and factors of landslide risks in the city of Dnipro
}

\section{T. P. Mokritskaya}

Oles Honchar Dnipro National University,Dnipro,Ukraine,mokritska@i.ua

Received: 03.04.2019

Received in revised form: 15.06 .2019

Accepted: 30.06 .2019
Abstract. The paper represents the research results as for the factors of such dangerous geological phenomenon as landslides in terms of geological medium of the city of Dnipro. It is emphasized that there are certain geological, geomorphological, and hydrogeological conditions favouring the development of a medium for landslide formation. Irrespective of long-term study of that phenomenon, spatiotemporal prognosis is a complex scientific problem requiring application of innovative ideas and scientific statements concerning both separate components of a geological medium and rather complex natural and technogenic system. The paper analyzes conditions of the development of deep landslides within the territory of the city of Dnipro connected with a geological structure in a scope going beyond traditional scope of engineering and geological studies. Despite wide occurrence of landslide developments within the territory of the region, landslide of the Dnipro region are not singled out as a separate regional type. According to different estimations, general number of landslides is more than 144 within the city of Dnipro. The studies are based on numerous calculations of slope stability indicating the importance of the occurrence of Pre-Quaternary deposits as the factor favouring deep landslide formations. Basing upon the processing of the geological studies, cartographic modeling of the surfaces of certain levels, their thickness, and analysis of landslides grouping within the areas of singled-out territories have been performed. Maps of the surfaces of reddish-brown $\left(\mathrm{N}_{2}-\mathrm{Q}_{1}\right)$ and grey-green $\left(\mathrm{N}_{1}-\mathrm{S}_{2}\right)$ clays as well as deposits of Obukhivska $\left(\mathrm{P}_{2} \mathrm{ob}\right)$ and Mezhyhirska $\left(\mathrm{P}_{3}\right.$ mž $)$ suites, representing together the rock thickness corresponding to Kharkiv Stage $\left(\mathrm{P}_{2-3} \mathrm{hr}\right)$, have been developed. It has been proved that occurrence mode of clays at the base of loessial soils creates certain conditions for the development of landslides being different in their mechanisms (i.e. cutting, slipping, and squeezing). An example of certain calculations of slope stability is given confirming the important role of argillaceous rocks in the formation of the zone of changed soil condition and property. It has been proved that occurrence mode of the rocks occurring lower than the depth of water erosion development should be studied thoroughly while designing landslide protection structures to obtain accurate model of the geological medium.

Keywords: landslide, clays, spatial model

\section{Про типи, умови та фактори розвитку зсувних процесів у м Дніпро}

\author{
Т.П. Мокрицька
}

\section{Дніпровський національний університет імені Олеся Гончара, Дніпро, Украӥна, mokritska@i.ua}

Анотація. В статті наведені результати встановлення регіональних факторів розвитку небезпечних геологічних явищ - зсувів на прикладі геологічного середовища м. Дніпро. До умов розвитку зсувів відносять геологічні, геоморфологічні, гідрогеологічні умови, які створюють середовище виникнення небезпечного явища. Незважаючи на тривале вивчення цього явища, просторово-часовий прогноз є складною науковою проблемою, що потребує застосування нових уявлень та наукових положень як про окремі компоненти геологічного середовища, так й про складну природно-техногенну систему. В даному досліджені розглянути умови розвитку глибоких зсувів на території міста Дніпро, які пов'язані з геологічною будовою у об’ємі, що перебільшує традиційний об'єм інженерно-геологічних досліджень. Незважаючи на широку поширеність зсувних явищ на території регіону, зсуви Дніпровського регіону не виділені як самостійний регіональний тип. Загальна чисельність зсувних явищ за різними оцінками складає понад 144 у межах міста Дніпро. Підставою для дослідження є результати багато чисельних розрахунків стійкості схилів, які вказують на важливу роль залягання до четвертинних відкладів як чинника, що сприяє формуванню глибоких зсувів. На підставі обробки матеріалів геологічних досліджень виконане картографічне моделювання поверхонь окремих горизонтів, їх потужності та аналіз групування зсувних явищ у межах виділених ділянок. 
Створені карти поверхонь червоно-бурих глин $\left(\mathrm{N}_{2}-\mathrm{Q}_{1}\right)$ та сіро-зелених глин $\left(\mathrm{N}_{1}-\mathrm{S}_{2}\right)$, також відкладів обухівський (Р2ob) та межигірський $\left(\mathrm{P}_{3} \mathrm{mž}\right)$ світ, які в сукупності представляють собою товщу порід, яка відповідає харківському “ярусу” (P2-3hr). Доведено, що умови залягання глин у основи лесових грунтів створює умови щодо розвитку зсувів різних за механізмами, а саме: зрізу, ковзання та роздавлювання. Наведений приклад певних розрахунків стійкості схилу, що підтверджують важливу роль глинястих порід у формуванні зони зміненого стану та властивостей грунтів. Доведено, що умови залягання гірських порід, що залягають нижче глибини розвитку водної ерозії, необхідно вивчати при розробці протизсувних споруд 3 метою створення точної моделі геологічного середовища.

Ключові слова: зсув, глини, просторова модель.

Introduction. Research of landslide developments is rather topical current scientific problem. Landslide process along with its accompanying conditions and factors has been already analyzed for a long time. That catastrophic natural and technogenic phenomenon results in considerable economic losses in the countries with rather high scientific achievements (Hirota, Konagai, Sassa, et al., 2019; Wooten, Witt, Miniat, Hales, Aldred, 2016). In terms of the countries with lower level of economic development, dangerous natural and, especially, geological processes cause a problem, which is not considered in time. Current studies of landslide developments are aimed at the solution of certain complex problems. Necessity of searching for innovative methods to analyze landslides and elaboration of scientific methods to prognosticate those phenomena were discussed at the international congress (Alcántara-Ayala, Sassa, Mikoš, et al., 2017). Landslides are studied at different levels from regional to local ones (H. Hong, Chong Xu, Dieu Tien, 2015; A. Ciampalini et al., 2016). Factors and conditions for the development of landslides in different regions are analyzed basing upon the innovative research methods (Choi, Raymond Cheung, 2018). Great attention is paid to the search for new techniques for regional prognosis of landslide developments (Iversona et al., 2015; Reichenbacha et al., 2018) involving neural network methodology as well (Le et al., 2018). New methods of spatiotemporal prognosis of landslides are being developed (Liao, et al., 2011; Reichenbacha et al., 2018). A problem concerning development of new devices to monitor dangerous processes is also rather topical (Jinesh Mehta, et al., 2017.). Gariano, Guzzetti (2016) have emphasized considerable effect of global warming upon the intensity of landslides all over the world. Thus, review of current studies of landslides worldwide demonstrates the necessity of the determining certain regularities in the formation of landslides as a regional dangerous phenomenon with the application of innovative ideas concerning specific geological environment.

Materials and methods. Landslide phenomena are well developed on the territory of Ukraine (Demchishin, 1982; Rud'ko, 2006). Research of the landslides within the territory of Dnipro city began in the 1930s. First notes on the available landslides are found in the materials of engineering and geological studies of the slopes of Zustrichna ravine due to the construction operations. In the 1960 s, engineering survey was performed along with the systematic descriptions of landslide processes. Considerable advance of landslides as well as the diversity of their forms and types was highlighted. Surface and deep flow slides, suffusion processes, and slips were identified. In the 1970s, a map of engineering and geological zoning was elaborated; monitoring of erosion and landslide developments within the ravines was completed. In the 1980s-90s, geological processes within the city area were monitored; cadastre of landslides was developed. Within the period of 2000-2014, experts of PivdenUkrheolohiia PC and other specialists carried out specific studies of landslide developments.

Despite wide occurrence of landslide developments within the territory of the region (Fig.1), landslides of the Dnipro region were not singled out as the specific regional type.

Features of geological structure, geomorphological, and hydrogeological factors are traditional issues favouring the development of landslides. Technogenic factors also belong to the mentioned ones. According to the geological studies (Nekriach, Maniuk, 2004), it is known that geological profile of the Dnipro region is represented by the formations of the Archean and Cainozoic erathems. The structure unites rocks of different age (from the Precambrian to Quarternary ones). Deposits of the Quaternary system convers all the territory like a blanket occurring on the sedimentary deposits of the Neogene, Paleogene, and crystalline formations. The geological structure contains separate levels of silty-clayed composition, which may be the medium for the development of landslide processes.

We have analyzed the mode of loessial thickness occurrence during the development of cartographic models of the probability of subsidental deformations (Mokrytska, et al., 2016). According to the features of granulometric composition, conditions, and properties, those levels may be a medium for the development of such natural and technogenic processes as: 


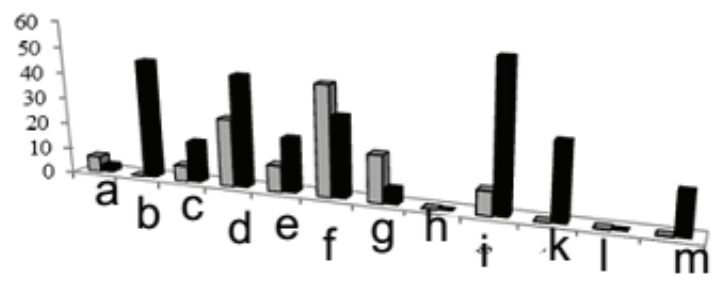

Fig. 1. Occurrence of landslide developments within the erosion systems of the Dnipropetrovsk region (1993).

Notes:

- Landslide developments; - Ravines.

a - River of Dnipro; b - River of Mokra Sura I; c - River of Sukha Sura; d - River of Mokra Sura II; e - River of Samotkan; f - River of Domotkan; g - River of Bezymiannaia; h - River of Kamenka; i - River of Saksahan; k - River of Bazavluk; 1 - River of Solionaia; m - River of Kamyshevataia Sura.

subsidence, subsidence deterioration, erosion, suffusion, and landslides.

According to the development mechanism, landslides in loessial soils are similar to flows, slidesflows, or suffusion-subsidental landslides. Studies of the features of landslide developments within the region have proved that that phenomenon is characterized by certain staging, manifesting deep landslides at different stages of the slope process development in terms of technogenesis (Mokritskaya, Shestopalov, 2014).

Formation of deep landslides may be connected with the peculiarities of the occurrence of Pre-Qua- posits of Obukhivska $\left(\boldsymbol{P}_{2} \boldsymbol{o b}\right)$ and Mezhyhirska $\left(\boldsymbol{P}_{3}\right.$ mž $)$ suites which represent together a thickness of rocks corresponding to Kharkiv stage $\left(\boldsymbol{P}_{2-3} \boldsymbol{h r}\right)$. Features of the mode of those deposits occurrence to determine conditions of the formation of deep landslides have not been studied before. The study involves reports on geological research dated back to 1962, 1964-1970, 1970-1974, and 2004. Candidate of Geological Sciences, Maniuk, V.V. helped correlate occurrence of the deposits being different in their origin and age.

Results and their discussions. After thorough study of the archive materials, the obtained data were used as the basis to create a database (Fig. 2) including

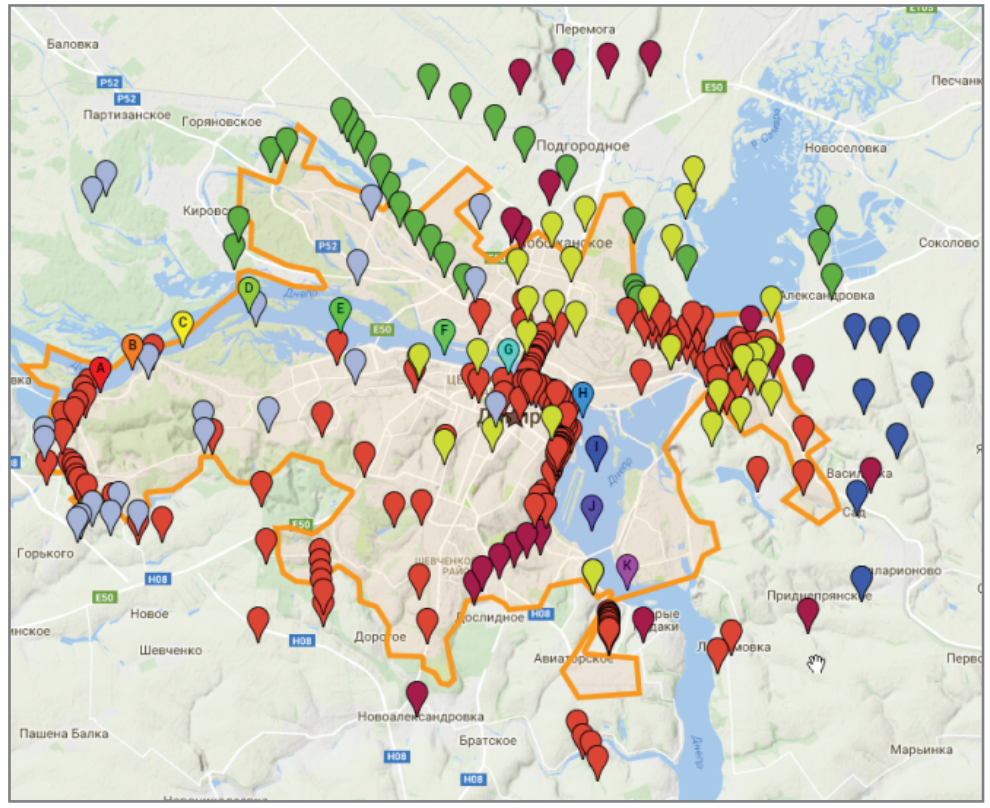

Fig. 2. Location of geological wells within the territory under study

ternary deposits as well. Pre-Quaternary deposits are represented by the abundant deposits of Neogene and Paleogene, i.e. unseparated levels of reddish-brown $\left(\mathrm{N}_{2}-\mathrm{Q}_{1}\right)$ and grey-green $\left(\mathrm{N}_{1}-\mathrm{S}_{2}\right)$ clays as well as de-
283 wells as well as the information on their location (WGS coordinates), identification number of a well, actual number of a well, stratigraphic indices, absolute elevation, and geological description. 

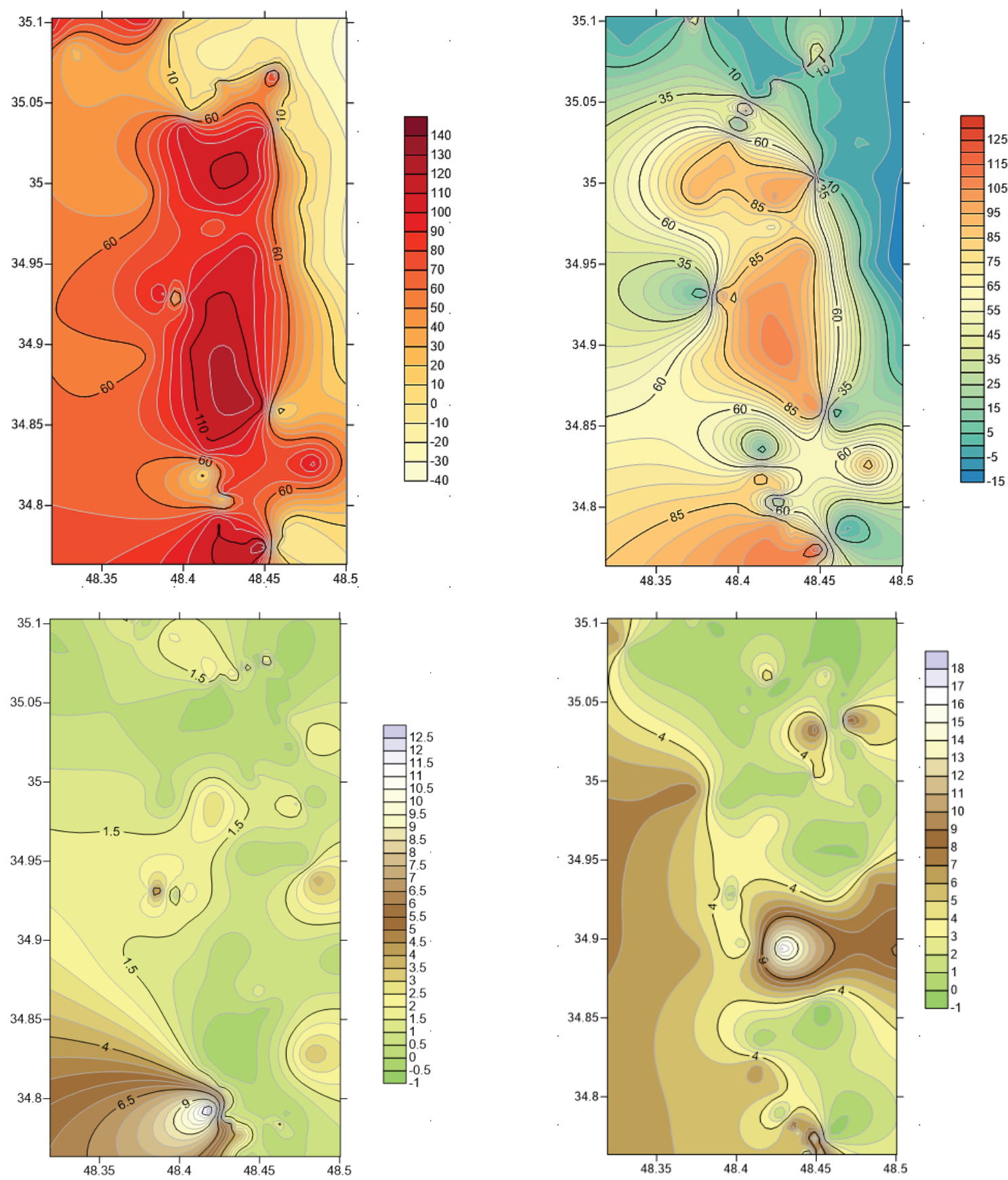

Fig.3. Contour map of the top of reddish-brown $\left(\mathrm{N}_{2}-\mathrm{Q}_{1}\right)$ and grey-green $\left(\mathrm{N}_{1}-\mathrm{S}_{2}\right)$ clays within the territory of the city of Dnipro and thickness maps (right-bank territory, scale is 1: 50000 ).

Demo version of the Surfer software was applied to generate a map of surfaces and thicknesses of the indicated levels of the Neogene and Paleogene deposits at a scale of 1:50000 (Fig. 3). Cartographic methods were involved to determine a wash zone of the deposits, to perform overlay mapping, and develop a cartographic model of the mode of the Neogene deposits occurrence within the floor of the Quaternary loessial deposits and the Paleogene deposits within the floor of the Neogene deposits.

Zoning of the territory under study was performed according to the mode of the Neogene deposits occurrence as the factor of landslide developments. Areas corresponding to the wash zones and availability of the Neogene deposits as well as to the areas differing in the surface inclination are separated (Fig.4). Uniting the tops of reddish-brown and greengrey clays into the joint model has made it possible to single out the wash zones of reddish-brown clays (area A). Along with the wash zones, there were highlighted the zones with normal, regular clay occurrence, with almost unchanged thickness (area B), and zones with irregular occurrence (area C), where clay thickness experienced gradual changes, from the considerable 


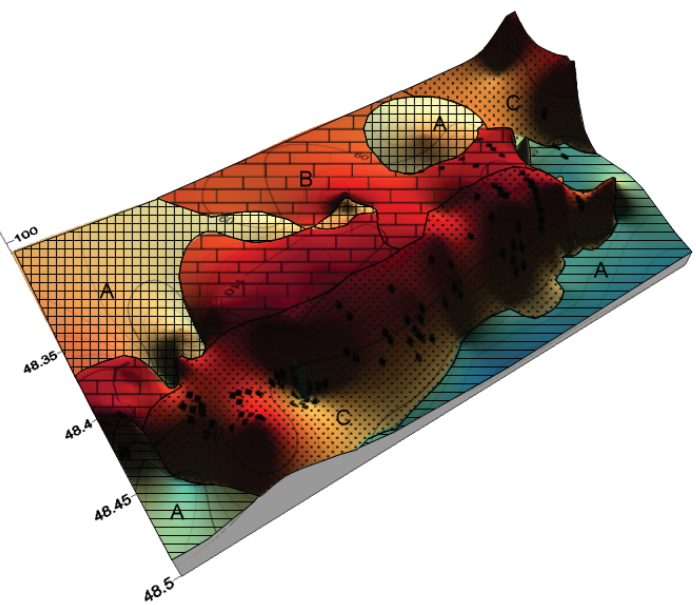

Fig. 4. Zoning map of the city territory in terms of landslide formation within the areas of Neogene clays being different in their occurrence mode.

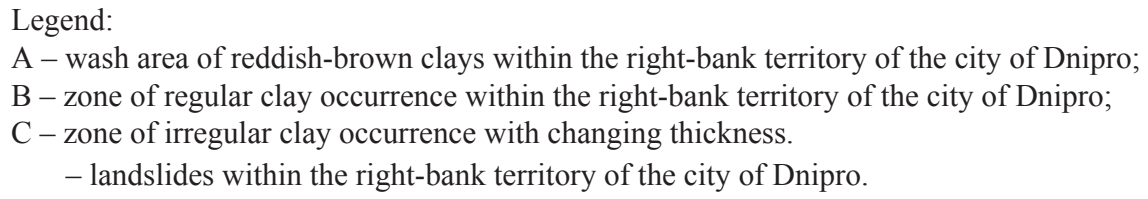

to medium-low ones with their following zero value. It is also possible to point out that the angle of soils occurrence is rather steep, more than $5 \%$, which, in case of clay deposits, may be a factor of landslide development in terms of slip type. Following stage of modeling included mapping of the areas of landslide development; generally, 133 areas were identified.

Analysis of the location of landslide development areas shows that there are no landslide developments within the wash zones of the Neogene deposits. Majority of the landslide formation areas is observed within the areas with irregular thickness of the Neogene clay deposits; minority number of those areas is within the zones of the Neogene deposits with regular mode of occurrence. The fact demonstrates that those are the composition, mode of occurrence, and condition of the Neogene deposits which are the factors effecting the development of landslide processes being different in their type. Within the type $\mathrm{B}$ areas, formation of the landslide of squeezing type is possible. Within the type $\mathrm{C}$ areas, slip landslide is possible.

In terms of the territory under consideration, the Paleogene deposits are available locally. However, since those formations may be considered as silty-clayed ones (in terms of their granulometric composition), and they may demonstrate rheological properties, then regularities of spatial changes in the occurrence mode of Obukhivska $\left(\boldsymbol{P}_{2} \boldsymbol{o b}\right)$ and Mezhyhirska $\left(\boldsymbol{P}_{3}\right.$ mž) suites have been analyzed (Fig. 5, 6).

The obtained models show incongruence of the regularities of spatial distribution of the deposits of Obukhivska $\left(\boldsymbol{P}_{2} \boldsymbol{o b}\right)$ and Mezhyhirska $\left(\boldsymbol{P}_{3}\right.$ mž $)$ suites.

Formation of the total surface of the Paleogene deposits roof and superimposing of the surface with the areas of landslide developments demonstrate possible effect of deeply occurring deposits upon the landslide formation within the surface deposits. That may be caused by the features of hydrogeological structure and changes in lithological composition or rock conditions within the zones of irregular occurrence, resulting in their changed permeability or strength and favouring the formation of the areas of plastic flow within the slope subsoil.

That indicates the necessity of the comprehensive analysis of geological structure of the urban territories to elaborate landslide protection strategy. Determining the effect of the occurrence mode of surface deposits upon the erodible level does not allow defining all the factors influencing the mechanism and conditions of landslide occurrence.

Those conclusions may be proved by the immediate stability calculations for the slopes being the medium for landslide development. Results of the stability calculation for possible landslide bodies within a certain area are given as the example.

Loessial deposits occurring on the Neogene argillaceous deposits and weathering crust of the ArcheanProterozoic rock deposits are involved into geological structure of the slope.

Calculations are performed with the help of the Geostab licensed software. Possibility to substantiate 

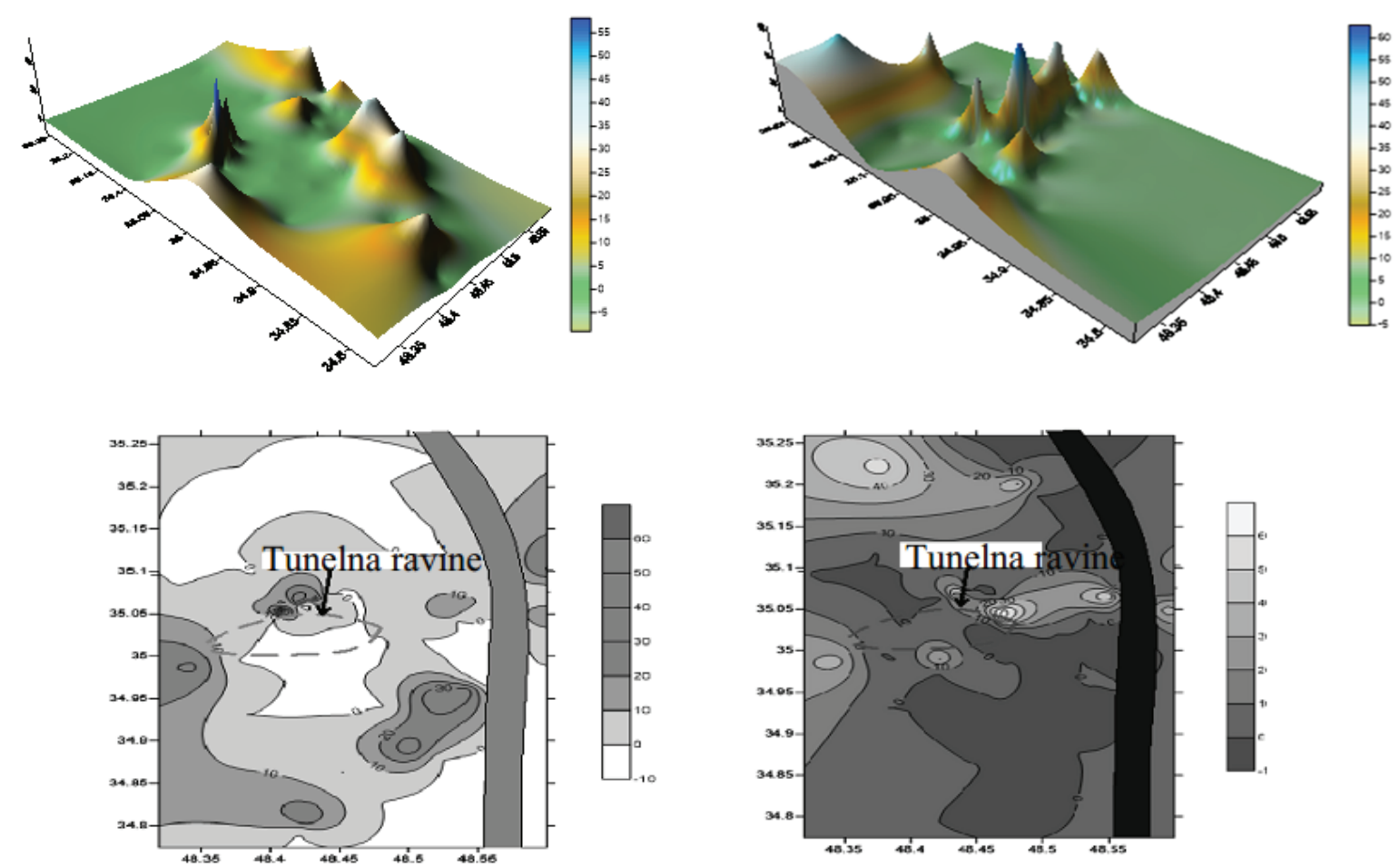

Fig. 5. Occurrence mode of the surfaces of certain levels of the Paleogene deposits - 3D model and isoline maps.

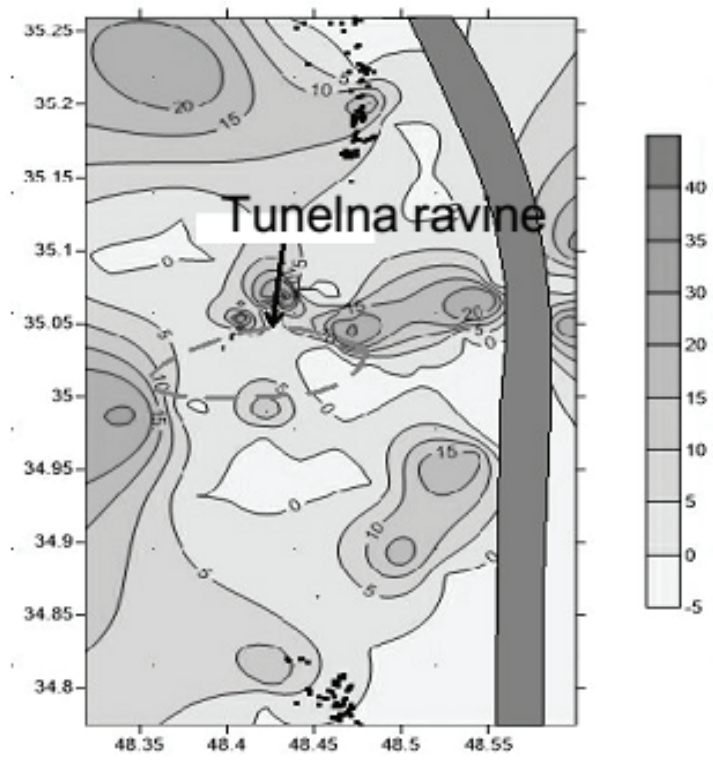

Fig. 6. Occurrence mode of Obukhivska and Mezhyhirska suites with the plotted landslide points.

the most probable landslide body location by solving optimization problem is the advantage of that software. While calculating, following variants of stability loss were considered: tion;

loss of slope stability in its natural (initial) condi-

effect of the additional load due to buildings; effect of the additional loads due to buildings and hydrostatic action of ground water;

effect of the additional loads due to buildings, hydrostatic flow action and consideration of the formation of the zone with changed slope stability;

Table 1 represents the data on physical and mechanical parameters having been used. According to the computational results, it has been determined that loss of slope stability is possible in terms of all the 

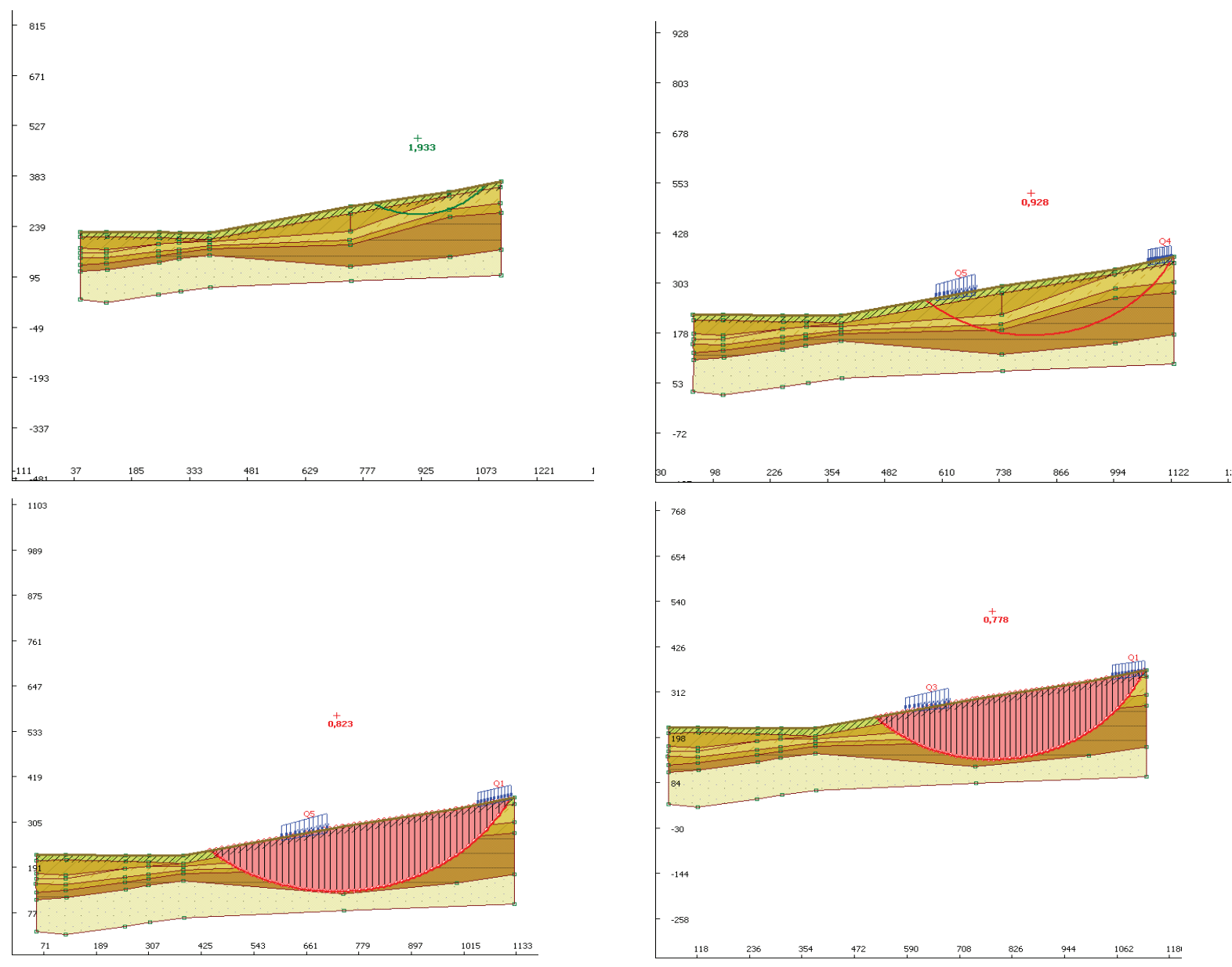

Fig. 7. The most probable landslides.

Legend:

- loessial deposits

- Clay deposits

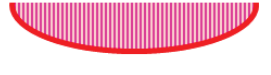

0,928
- the most probable landslides

- coefficient of stability (slump). variants taking into account additional loads. However, in terms of different variants, not only the coefficient value but also the volume of possible landslide body experiences certain changes.

Conclusions. According to the obtained modeling results, analysis of cartographic material, and calculations, following conclusions may be drawn:

loss of stability of the slope being stable in its natural condition, is possible in terms of technogenic effect as the results of mechanical and hydrodynamics actions;

in terms of different variants of changes in slope condition, not only surface loessial but also argillaceous deposits may be the medium for landslide developments;

occurrence mode of argillaceous soils is the factor effecting possible landslide developments;

while elaborating landslide protection systems, it is required to study mode of occurrence, composition, and properties of argillaceous soils.

Acknowledgements. This work was supported by the Ministry of Education and Science of Ukraine, state budget issue № 0117U001210

\section{References}

Alcántara-Ayala I., Sassa K., Mikoš M. et al., 2017. Int J Disaster Risk Sci (2017) 8: 498. https://doi. org/10.1007/s13753-017-0139-4

Choi K.Y., Raymond W.M., Cheung, 2013. Landslide disaster prevention and mitigation through works in Hong Kong. Journal of Rock Mechanics and Geotechnical Engineering Volume 5, Issue 5, October 2013, 354-365, doi: https://doi. org/10.1016/j.jrmge.2013.07.007

Ciampalini A., Raspini F., Lagomarsino D., Catani F., Casagli N., 2016. .Landslide susceptibility map 
Table 1. Physical and mechanical properties of the soils in terms of calculation variant taking into account effect of the additional loads due to buildings

\begin{tabular}{|c|l|c|c|c|}
\hline \multirow{2}{*}{$\begin{array}{c}\text { Number } \\
\text { of layers }\end{array}$} & & \multicolumn{3}{|c|}{ Index } \\
\cline { 2 - 5 } & & $\gamma, \mathrm{kN} / \mathrm{m}^{3}$ & $\mathrm{c}, \mathrm{kPa}$ & $\varphi$, degree \\
\hline 1 & Loose & 18 & 48 & 11 \\
\hline 2 & Loamy soil & 19.01 & 48 & 11 \\
\hline 3 & Loamy soil & 19.01 & 48 & 11 \\
\hline 4 & Loamy soil & 15.38 & 9 & 17 \\
\hline 5 & Hard loamy sand & 16.61 & 33 & 17 \\
\hline 6 & Medium-hard loamy soil & 19.16 & 13 & 23 \\
\hline 7 & Plastic loamy sand & 19.11 & 31 & 6 \\
\hline 8 & Hard loamy soil & 19.68 & 26 & 26 \\
\hline 9 & Plastic loamy sand & 20.08 & 21 & 9 \\
\hline 10 & Hard loamy soil & 19.88 & 74 & 18 \\
\hline 11 & Hard clay & 19.94 & 70 & 17 \\
\hline 12 & Hard clay & 18.34 & 15 & 12 \\
\hline 13 & Fine sand & 19.68 & & \\
\hline
\end{tabular}

Key to Table 1:

$\gamma$-density of soil; $\mathrm{c}$ - cohesion; $\phi$ - friction angle

refinement using PSInSAR data/Remote Sensing of Environment, Volume 184, 302-315 https://doi. org/10.1016/j.rse.2016.07.018

Demchishin M.G., 1982. Prognoz i preduprezhdeniye opolznevykh yavleniy na territorii Ukrainy [Forecast and prevention of landslide phenomena in Ukraine].K.: IGSNAS. - 53 s. (in Russian).

Gariano S. L., Guzzetti F., 2016. Landslides in a changing climate. Earth-Science Reviews Volume 162, November, 227-252 https://doi.org/10.1016/j. earscirev.2016.08.011

Hong H., Xu Chong, Tien Dieu, 2015. BLandslide Susceptibility Assessment at the Xiushui Area (China) Using Frequency Ratio Model. Procedia Earth and Planetary Science, Volume 15, 513-517 https://doi.org/10.1016/j.proeps.

Iversona R.M., , Georgea D.L., Allstadtb K. et al., 2015 . Landslide mobility and hazards: implications of the 2014 Oso disaster Earth and Planetary Science Letters Volume 412, 15 February 2015, 197-208. https://www.sciencedirect.com/science/article/ pii/S0012821X1400781X?via\%3Dihub https://doi.org/10.1016/j.eps1.2014.12.020

Jinesh M., Vinayak M., Dhruv A., Atish and Krishna P., 2017. Pothole Detection and Analysis System (PoDAS) for Real Time Data Using Sensor Networks. Journal of Engineering and Applied Sciences, 12: 3090-3097.

Le Q.H. et al. (2018) TXT-tool 1.084-3.1: Landslide Susceptibility Mapping at a Regional Scale in Vietnam. In: Sassa K. et al. (eds) Landslide Dynamics: ISDR-ICL Landslide Interactive Teaching Tools. Springer, Cham K. Hirota, K. Konagai, K. Sassa et al, Landslides 16: 189. https://doi.org/10.1007/ s10346-018-1100-3

Liao Z., Y. Hong, , D. Kirschbaum, et al. 2011. Nat Hazards (2011) 58: 325. https://doi.org/10.1007/s11069010-9670-y

Lombardo L., P. Martin Mai, 2018. Presenting logistic regression-based landslide susceptibility results /Engineering Geology Volume 244, 3 October 2018, 14-24 https://doi.org/10.1016/j. enggeo.2018.07.019

Nekryach, A. I. Manyuk, V. V, 2004. Zvit pro heolohichne 
dovyvchennya ranishe zakartovanykh ploshch masshtabu 1:200 000, Arkush M-36-XXXVI. [The State Geological Map of Ukraine in the scale 1:200 000], Kyiv, UkrSGRI, 127.

Mokritskaya T.P., Samoylych K. O. 2017. Attempt to Create a Cartographic Forecast Model of Subsidence Degradation for the Right Bank Area of the City Dnipro. Dniprop. Univer. bulletin, Geology, geography., 25(2), 117-122. doi:10.15421/111726

Mokritskaya T.P., Shestopalov V.M., 2015. Landslide Processes of Active Phase of under Conditions of Technogenesis with the Example of Pridneprovsk Industrial Region of Ukraine. - Engineering Geology for Society and Territory. - Springer, Vol. 5, 663-665.

Reichenbacha P., Rossia M., Malamudb B. D., Mihirb M., Guzzetti F., 2018. A review of statistically-based landslide susceptibility models. Earth-Science Reviews 180 (2018) 60-91.

Rudko G .I., 2006. Opolzni i drugiye geodinamicheskiye protsessy gornoskladchatykh oblastey Ukrainy (Krim, Karpati): [Landslides and other geodnamic processes in the mining areas of Ukraine (Crimea, Carpathians)]. Zadruga, 624 ((In Russian).

Wooten R.M., Witt A.C., Miniat C.F., Hales T.C., Aldred J.L, 2016. Frequency and Magnitude of Selected Historical Landslide Events in the Southern Appalachian Highlands of North Carolina and Virginia: Relationships to Rainfall, Geological and Ecohydrological Controls, and Effects. In: Greenberg C., Collins B. (eds) Natural Disturbances and Historic Range of Variation. Managing Forest Ecosystems, vol 32. Springer, Cham 